\title{
Accumulation of red tide toxins in larger size fractions of zooplankton assemblages from Massachusetts Bay, USA
}

\author{
Jefferson T. Turner ${ }^{1, *}$, Gregory J. Doucette ${ }^{2,3}$, Christine L. Powell ${ }^{2}$, David M. Kulis ${ }^{4}$, \\ Bruce A. Keafer ${ }^{4}$, Donald M. Anderson ${ }^{4}$ \\ ${ }^{1}$ Center for Marine Science and Technology, University of Massachusetts Dartmouth, 706 South Rodney French Boulevard, \\ New Bedford, Massachusetts 02744, USA \\ ${ }^{2}$ Marine Biotoxins Program, NOAA/NOS Center for Coastal Environmental Health \& Biomolecular Research, \\ 219 Fort Johnson Road, Charleston, South Carolina 29412, USA \\ ${ }^{3}$ Marine Biomedical \& Environmental Science, Medical University of South Carolina, 221 Fort Johnson Road, Charleston, \\ South Carolina 29412, USA \\ ${ }^{4}$ Biology Department, Woods Hole Oceanographic Institution, Woods Hole, Massachusetts 02543, USA
}

\begin{abstract}
Phytoplankton toxins undergo trophic transport and accumulation in marine food webs, causing vectorial intoxication of upper-level consumers such as fishes, seabirds, and marine mammals. An entry point for phytoplankton toxins into these pelagic trophic pathways is frequently the herbivorous zooplankton. During the 1995 spring-summer red tide season in Massachusetts Bay, we examined accumulation of paralytic shellfish poisoning (PSP) toxins from the dinoflagellate Alexandrium spp. in various plankton size fractions $(20-64,64-100,100-200,200-500$, and $>500 \mu \mathrm{m})$, and identified the relative composition of the zooplankton in these size fractions. Toxin levels were estimated by both high-performance liquid chromatography (HPLC) and a receptor-binding assay, the latter based on sample toxic potency. Although no PSP toxicity was detected in nearshore shellfish by routine monitoring programs using the mouse bioassay, positive responses were detected in zooplankton size fractions with the more sensitive HPLC and the receptor assay methods. The toxin signal was disproportionately concentrated in the larger zooplankton size fraction, frequently dominated by large copepods such as Calanus finmarchicus and Centropages typicus, which comprised only a small portion of total zooplankton abundance in quantitative samples obtained with $100 \mu \mathrm{m}$ mesh nets. By comparison, signal levels were low or undetectable in the smaller size fraction, which contained the overwhelmingly most-abundant zooplankters such as protists, copepod nauplii and copepodites and adults of small copepods such as Oithona similis, Paracalanus parvus, and Pseudocalanus spp. The larger toxin-accumulating copepods could provide a direct trophic linkage for vectorial intoxication of baleen whales that are known to feed upon such copepods.
\end{abstract}

KEY WORDS: Red tide $\cdot$ Harmful algal blooms $\cdot$ Zooplankton $\cdot$ Copepods $\cdot$ Algal toxins $\cdot$ Vectorial intoxication · Massachusetts Bay · Gulf of Maine

Resale or republication not permitted without written consent of the publisher

\section{INTRODUCTION}

Marine phytoplankton toxins can cause finfish mortality and shellfish toxicity, as well as poisoning or death of humans, marine mammals and seabirds that

*E-mail: jturner@umassd.edu ingest contaminated fish or shellfish (Anderson \& White 1992, Baden \& Trainer 1993, Turner \& Tester 1997, Turner et al. 1998b). Accumulation and transport of these toxins through feeding interactions in pelagic food webs can also cause vectorial intoxication of consumers at higher trophic levels that are not direct consumers of toxic phytoplankton. The pioneer- 
ing work of White (1977, 1979, 1980, 1981) on accumulation of paralytic shellfish poisoning (PSP) toxins in various compartments of zooplankton communities indicated that food-web transport of these toxins could cause fish kills in the Bay of Fundy. The dinoflagellates White classified as Gonyaulax excavata are now viewed as members of the genus Alexandrium (Moestrup \& Larsen 1990). There have been few subsequent field studies on vectorial transport of dinoflagellate toxins to upperlevel consumers via zooplankton (Tester et al. 2000).

A major obstacle to studies of vectorial intoxication through zooplankton pathways has been the difficulty of measuring phytoplankton toxins in the ppb range found in field zooplankton populations. Recent advances in analytical techniques such as highperformance liquid chromatography (HPLC) (Oshima 1995), immunoassays and receptor-binding assays (Van Dolah et al. 1994, Cembella et al. 1995), capillary electrophoresis (Shea 1997), and LC-tandem mass spectrometry (Lefebvre et al. 1999) allow detection of phycotoxins or their activity at concentrations low enough for detection in field populations of zooplankton.

During the 1995 spring-summer bloom period of Alexandrium spp. in Massachusetts Bay, we measured PSP toxin levels in various size fractions of field zooplankton populations. Since 2 species of Alexandrium (A. tamarense and A. fundyense) can co-occur in the southern Gulf of Maine and Massachusetts Bay (Anderson 1997), and these are not readily distinguishable without considerable effort, we hereafter use only the genus name to refer to toxic Alexandrium spp. in our study area. PSP toxin levels were determined using HPLC and a saxitoxin receptor-binding assay (Doucette et al. 1997), employed here in a field study for the first time. Our goal was to measure PSP accumulation in zooplankton, which are the entry points to food webs that are thought to have caused fatal vectorial intoxication of marine mammals in these waters (Geraci et al. 1989).

\section{METHODS}

Study site. The site chosen for our study, Massachusetts Bay, is an open embayment offshore of Boston, defined by Cape Ann at the northern boundary and Cape Cod at the southern boundary, with Stellwagen Bank lying at the outer edge of the Bay (Fig. 1). Stellwagen Bank is a shallow, highly productive offshore embankment of about $20 \mathrm{~m}$ depth that is known as a habitat for several species of endangered marine mam- mals. It has recently been designated as a marine sanctuary. The areas just south of Boston Harbor, known as the 'South Shore', experience outbreaks of PSP shellfish toxicity every several years during the spring and early summer months. The last significant outbreak was recorded in 1993, although toxic cells are present in the bay annually.

The source of Alexandrium blooms in Massachusetts Bay has been suggested to be upstream in the Casco Bay/Kennebec River area of southern Maine (Franks \& Anderson 1992, Anderson, 1997). Alexandrium populations are transported by the Western Maine Coastal Current, which runs from northeast to southwest, impacting the coastlines of southern Maine, New Hampshire and Massachusetts, with inputs into Massachusetts Bay entering near Cape Ann.

Sampling. Samples for zooplankton size fractionation were collected on 4 cruises during April, May, and June 1995 (Fig. 1, Table 1). Temperature and salinity data were collected using a Seabird SeaCat CTD profiler \#19 and initially processed using Seabird's software. Final processing to produce selected contours of salinity, temperature, and cell concentration was completed using Matlab routines that included the Massachusetts Bay coastline. Satellite data of sea-surface temperature (SST) were also downloaded through NOAA's Coastwatch node and analyzed during the bloom season from April-June 1995.

Samples for Alexandrium abundance were collected with Niskin bottles at all stations, from the surface, and at 10 and $20 \mathrm{~m}$ depths. Two-liter samples were sieved onto $20 \mu \mathrm{m}$ mesh Nitex screens, and the phytoplankton retained on the screens were backwashed and preserved with borate-buffered formalin (5\% final concentration). Samples were stored in the dark, and refrigerated until analyses. Since Alexandrium cells were usually located primarily in the upper mixed layer (0 to $10 \mathrm{~m}$ ) (Franks \& Anderson 1992), the $20 \mathrm{~m}$ samples were archived and not analyzed.

Zooplankton were usually collected at 3 stations on each transect, generally at the most offshore, the most inshore, and an intermediate station (Fig. 1). At each station where zooplankton size fractions were obtained, 
Fig. 1. Station locations for cruises in Massachusetts Bay during 1995 spring-summer bloom season of Alexandrium spp. Zooplankton/toxin stations are circled
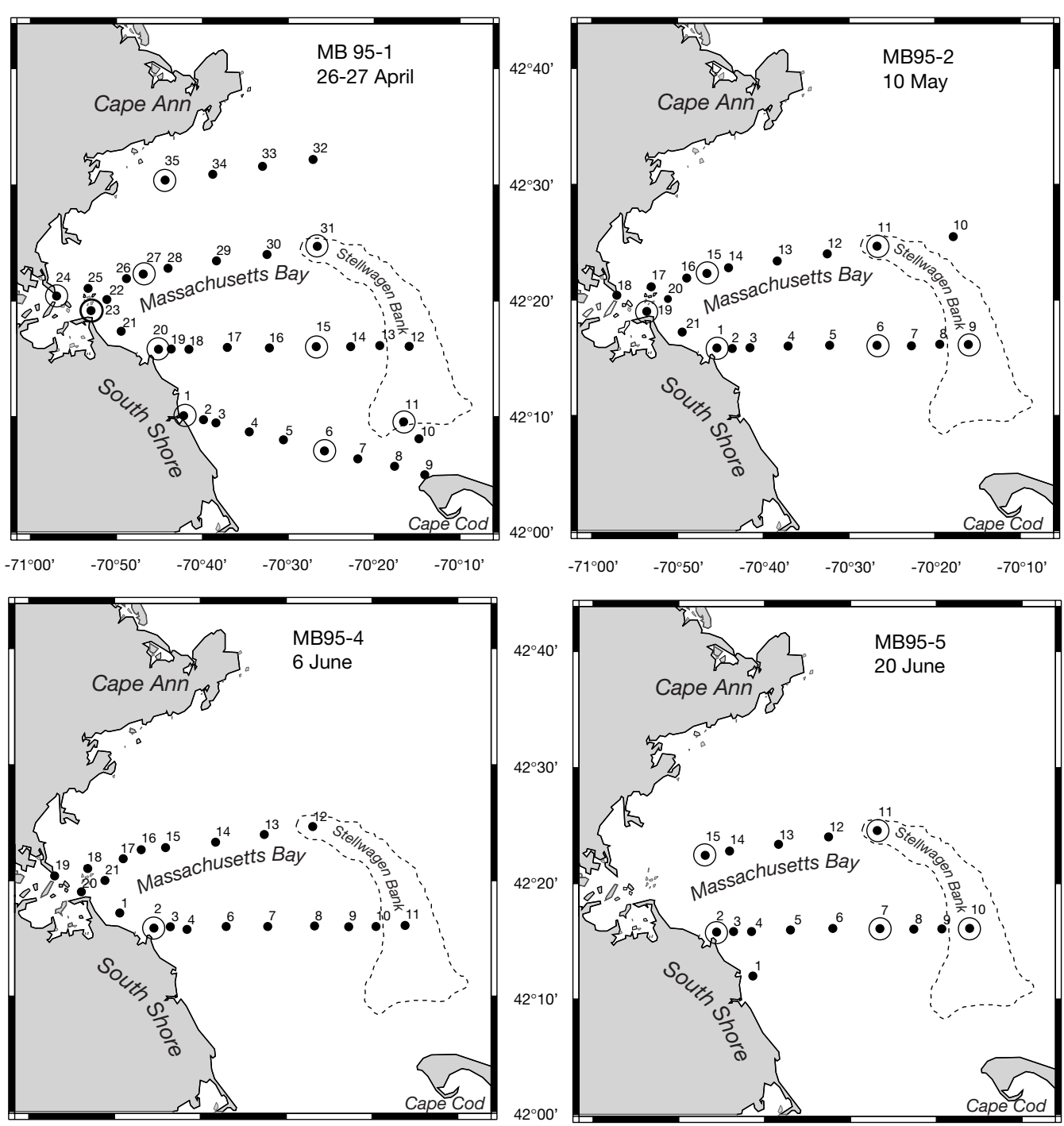

we sampled for PSP toxins in, and taxonomic composition of, the microzooplankton (20 to 64 and 64 to $100 \mu \mathrm{m})$ and mesozooplankton (100 to 200, 200 to 500, $>500 \mu \mathrm{m})$ fractions.

For microzooplankton, surface water was collected by running water from a deck hose into a $20 \mu \mathrm{m}$ mesh net hanging over the side of the boat. Water was passed through this net for approx. 15 to $30 \mathrm{~min}$ at each station, obtaining total samples estimated to represent $>100 \mathrm{~m}^{3}$.

For collection of mesozooplankton, 2 horizontal net tows were made with $0.5 \mathrm{~m}$ diam., $100 \mu \mathrm{m}$ mesh nets from just below the surface. This approach was adopted so that net tows would come from the same depth strata as the water for dinoflagellates and microzooplankton. First, a quantitative timed tow was made using a net equipped with a flowmeter (General Oceanics Model 2030), and all zooplankton were pre- served immediately in 5 to $10 \%$ formalin:seawater solutions for quantitative taxonomic analyses. Care was taken to ensure that flowmeters were still turning upon retrieval, indicating that there was no net clogging. If clogging occurred, the tow was repeated for shorter time periods, until there was no clogging. Generally, the quantitative tows lasted $<2 \mathrm{~min}$. Immediately after the quantitative tow, a second nonquantitative tow was made with the same net for collection of mesozooplankton for toxin analyses. These tows were made without regard to flowmeter readings, and generally lasted $10 \mathrm{~min}$, whether there was net clogging or not. The purpose of the qualitative tows was to collect sufficient zooplankton biomass for accurate detection of a PSP toxin signal, if present. The long towing time required to obtain sufficient zooplankton biomass usually resulted in net clogging, precluding quantitative measurements of animals $\mathrm{m}^{-3}$ or zooplank- 
ton biomass $\mathrm{m}^{-3}$ for these tows. However, plankton from these tows were processed quantitatively in order to provide quantitative measurements of PSP toxin levels and percentage composition comprised by various zooplankton taxa in different size fractions (see below).

Zooplankton size-fractionation for toxin and community composition analyses. The catch from the qualitative tows was fractionated through sequential meshes of 500,200 , and $100 \mu \mathrm{m}$ to obtain zooplankton fractions of $>500,200$ to 500 , and 100 to $200 \mu \mathrm{m}$. The slurry of plankton in these size fractions was then rinsed and consolidated by squirting with $20 \mu \mathrm{m}$ screened natural seawater (which would not have contained the 30 to $40 \mu \mathrm{m}$ diam. Alexandrium cells), scraped off meshes with spatulas, and packed into aliquots of $1 \mathrm{ml}$ in plastic syringes with the tips cut off. The plungers of the syringes were then used to expel the $1 \mathrm{ml}$ aliquot of wet plankton into preweighed plastic centrifuge tubes containing $1 \mathrm{ml}$ of $0.1 \mathrm{~N} \mathrm{HCl}$. Tubes with plankton size fractions in acid were then frozen for toxin analyses ashore. The remainder of the slurry of each size fraction was preserved in 5 to $10 \%$ formalin-seawater solutions for microscopic analyses of the relative taxonomic composition of each size fraction.

The microplankton caught by the $20 \mu \mathrm{m}$ mesh net filtering water from the deck hose was poured onto a $20 \mu \mathrm{m}$ mesh sieve, and then backwashed with filtered seawater. This $>20 \mu \mathrm{m}$ suspension was split into 2 aliquots of approx. 100 to $500 \mathrm{ml}$ each. One of these was filtered onto a $47 \mu \mathrm{m}$ diam. Whatman GF glass-fiber filter, which was then placed in a preweighed plastic centrifuge tube in $1 \mathrm{ml}$ of $0.1 \mathrm{~N} \mathrm{HCl}$ and frozen for toxin analyses. The other aliquot was screened through sequential sieves of 100,64 , and $20 \mu \mathrm{m}$. The $>100 \mu \mathrm{m}$ fraction was discarded, and the remaining 64 to 100 and 20 to $64 \mu \mathrm{m}$ size fractions were backwashed into $15 \mathrm{ml}$ centrifuge tubes with filtered seawater. Aliquots of $0.5 \mathrm{ml}$ were removed from each fraction, added to $100 \mathrm{ml}$ jars, and preserved in Utermöhl's solution (Guillard 1973), after bringing the total volume to approx. $100 \mathrm{ml}$ with filtered seawater. These samples were later examined ashore for relative taxonomic composition of the microplankton in each fraction. The remaining $14.5 \mathrm{ml}$ of each aliquot were filtered onto glass-fiber filters, which were placed in preweighed plastic centrifuge tubes in $1 \mathrm{ml}$ of $0.1 \mathrm{~N} \mathrm{HCl}$ for toxin analyses.

Zooplankton abundance and community-composition analyses. Mesozooplankton from quantitative tows were transferred to $70 \%$ ethanol solutions and split with a Folsom plankton splitter to obtain aliquots of approx. 300 to 500 animals each. Animals in these aliquots were counted and identified to the lowest possible taxonomic level with a dissecting microscope. Abundances were calculated as animals $\mathrm{m}^{-3}$. Meso- zooplankton in size fractions from qualitative tows were similarly split, counted, and identified, and abundances were presented as relative percentages of animals per aliquot. Microzooplankton in Utermöhl's preserved samples were examined in $1 \mathrm{ml}$ aliquots in a Sedgwick-Rafter cell with a compound microscope, counted and identified, and presented as relative percentages of animals observed. Qualitative observations on presence and relative abundance of dinoflagellates were also made during examination of these aliquots.

Alexandrium abundance. An immunofluorescence labeling protocol was used to identify and quantify Alexandrium cells with a genus-specific antibody probe (M8751-1; Adachi et al. 1993, Sako et al. 1993) known to react with cell-surface antigens of Alexandrium spp. from the Gulf of Maine region. This probe has been shown to label cultured Alexandrium cells with an acceptable level of consistency regardless of physiological condition.

To stain the cells, the preserved field samples for Alexandrium counts were further concentrated by settling and removal of the overlying seawater (final volume $=2 \mathrm{ml}$ from a $2 \mathrm{l}$ water sample). A $1 \mathrm{ml}$ aliquot of the concentrate was transferred to a siliconized microcentrifuge tube, where the particulate material was pelleted by centrifugation (swinging bucket type; $5000 \times g$ for $5 \mathrm{~min}$ ). The supernatant was removed and $5 \%$ normal goat serum (NGS; Sigma \#G-9023) in 0.02M PBS added as the blocking agent. After incubation for $30 \mathrm{~min}$ on a LabQuake Supplier shaker, the material was pelleted, the supernatant removed and $100 \mu \mathrm{l}$ of primary monoclonal antibody (M8751-1 in 5\%NGS) were added and incubated with mixing for $30 \mathrm{~min}$. After washing 3 times with $0.5 \%$ NGS in 0.02 M PBS by centrifugation to remove the excess primary antibody, $100 \mu \mathrm{l}$ of a secondary polyclonal antibody, goat anti-mouse IgG (heavy + light chain) conjugated to fluorescein isothiocyanate (FITC; Molecular Probes Inc. \#F-2761; diluted 1:300 v/v with 5\% NGS/PBS), were added and incubated for another $30 \mathrm{~min}$. The stained samples were washed twice with $0.02 \mathrm{M} \mathrm{5 \%} \mathrm{NGS/PBS,}$ resuspended in $100 \mu \mathrm{l}$ PBS, and $25 \mu \mathrm{l} 80 \%$ glycerol/ PBS were added. The sample was loaded into a Palmer-Maloney counting chamber and examined using a Zeiss epifluorescence microscope equipped with a FITC filter set (excitation = BP450-490; emission = LP 520). The full slide was counted for the presence of the bright green stain on the surface of the target Alexandrium cells, while red fluorescence, indicative of chlorophyll $a$, was also observed internally. Positive controls using cultured Alexandrium cells were stained with each batch of samples to ensure that the procedure worked properly. 
Toxin analyses. Samples for toxin analyses were sonified, heated to $97^{\circ} \mathrm{C}$ for $5 \mathrm{~min}$ in a water bath for toxin hydrolysis, centrifuged, and the supernatants were passed through C-18 Sep-Pak cartridges. Aliquots were removed for both HPLC and receptorbinding assay analyses. The saxitoxin receptor assay is a rapid, high-throughput, competitive binding assay based on the interaction of saxitoxin and all other PSP derivatives with their biological target, the voltagedependent sodium channel (Doucette et al. 1997). Values generated by this assay for extracts of Alexandrium cultures correspond closely to those obtained by HPLC, and the current work provides a similar comparison for estimating PSP toxin activity in size fractions of field material dominated by either Alexandrium spp. or various zooplankters. The assay protocol and calculations of sample values used herein follow those described by Doucette et al. (1997), except that a microplate scintillation counter (Wallac Inc., Gaithersberg, Maryland), rather than a conventional liquid scintillation counter, was employed to assess the assay's radioactive endpoint. Briefly, the receptorbinding assay is performed in a microplate filtration format and involves the incubation of a rat brain synaptosome preparation containing the receptors with ${ }^{3} \mathrm{H}$-STX and unlabeled PSP toxins contained in a standard or sample. After removal of unbound toxin by washing, the remaining bound radioactivity (i.e., $\left.{ }^{3} \mathrm{H}-\mathrm{STX}\right)$, which is inversely and quantitatively related to the concentration of PSP-like activity in a sample, is determined by microplate scintillation counting. Toxin concentrations are expressed in terms of saxitoxin equivalents (STX equiv).

The receptor assay was used as an initial screen for the presence of PSP-like activity in the size-fractionated samples. Since extracts with a toxicity of ca $50 \mathrm{nM}$ STX equiv or less were run undiluted on the assay, such samples having a highly acidic $\mathrm{pH}$ of $<1$ tended to yield false positive results and were not considered further. If an extract of any size fraction for a given station had a toxicity $>50 \mathrm{nM}$ STX equiv, then all size fractions from that station were also analyzed by HPLC. Although samples for toxin accumulation in zooplankton were collected at 21 stations, by the criteria given above, toxin levels were measured with both the HPLC and the receptor-binding assay in all size fractions from a total of 10 stations (Table 1).

HPLC analysis followed the methods described in Anderson et al. (1994), except that analysis for C toxins was not performed since the samples were previously hydrolyzed. Toxin concentrations of the individual derivatives were converted into STX equivalents (382 for dcGTX2 and 935 for dcGTX3) using the factors given by Oshima et al. (1992) for direct comparison to receptor assay results.

\section{RESULTS}

\section{Shellfish toxicity and Alexandrium distributions}

Shellfish toxicity was not recorded within Massachusetts Bay in 1995, but toxicity was recorded in shellfish from adjacent waters of southern Maine, New Hampshire and northern Massachusetts (D. Whittaker \& J. Hurst pers. comm.).

Alexandrium was present in Massachusetts Bay during all cruises, but at most stations cells were

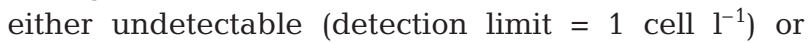

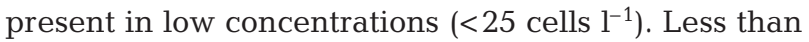
10 cells $1^{-1}$ were recorded for Cruise 95MB1 (data not shown), but during Cruise 95MB2 on 10 May 1995, a population of Alexandrium was detected offshore near the northwest corner of Stellwagen Bank (Stn 11), with a maximum abundance of approx. 50 cells $\mathrm{l}^{-1}$ (Fig. 2a). This low level population was near a very weak front associated with slightly warmer and slightly fresher water $\left(8^{\circ} \mathrm{C} ; 31.0\right.$ to 31.5 psu, Fig. $\left.2 \mathrm{~b}, \mathrm{c}\right)$ than the ambient Gulf of Maine waters. The likely source of these cells was from the Casco Bay region, carried to the south in the Western Maine Coastal Current (Anderson 1997). A sea-surface temperature (SST) image on 9 May 1995 indicated a downwelling condition which compressed the warmer waters of the Western Maine Coastal Current against the coast during this time (Fig. 3 left panel). Rapid delivery of toxic cells from the north into Massachusetts Bay can occur under these conditions (Franks \& Anderson 1992, Anderson 1997). By 28 May, SST imagery revealed that surface waters north of Cape Ann had generally warmed from $8.5-10.5^{\circ} \mathrm{C}$ to $12-13^{\circ} \mathrm{C}$ (note larger area covered by red and orange in Fig. 3, right panel, compared to area of light blue and yellow in Fig. 3, left panel), and that the coastal current had widened to the east, most likely keeping any Alexandrium populations away from nearshore (Fig. 3, right panel; Keafer \& Anderson 1993). During this late May period, strong upwelling conditions were detected nearshore off southern Maine, visible as an orange patch of 10 to $11^{\circ} \mathrm{C}$ surface water immediately offshore from the Maine-New Hampshire state line, shown in Fig. 3, right panel. During subsequent cruises, cell concentrations were near detection limits, except for several offshore stations located near the southern flank of Stellwagen Bank where approx. 25 cells $\mathrm{l}^{-1}$ were recorded during Cruise 95MB4 on 6 June 1995 (data not shown). This was probably another very weak pulse of cells originating from the north that passed through the offshore areas of Massachusetts Bay. The northeast winds needed to drive these cells into inner portions of the Bay did not occur. 

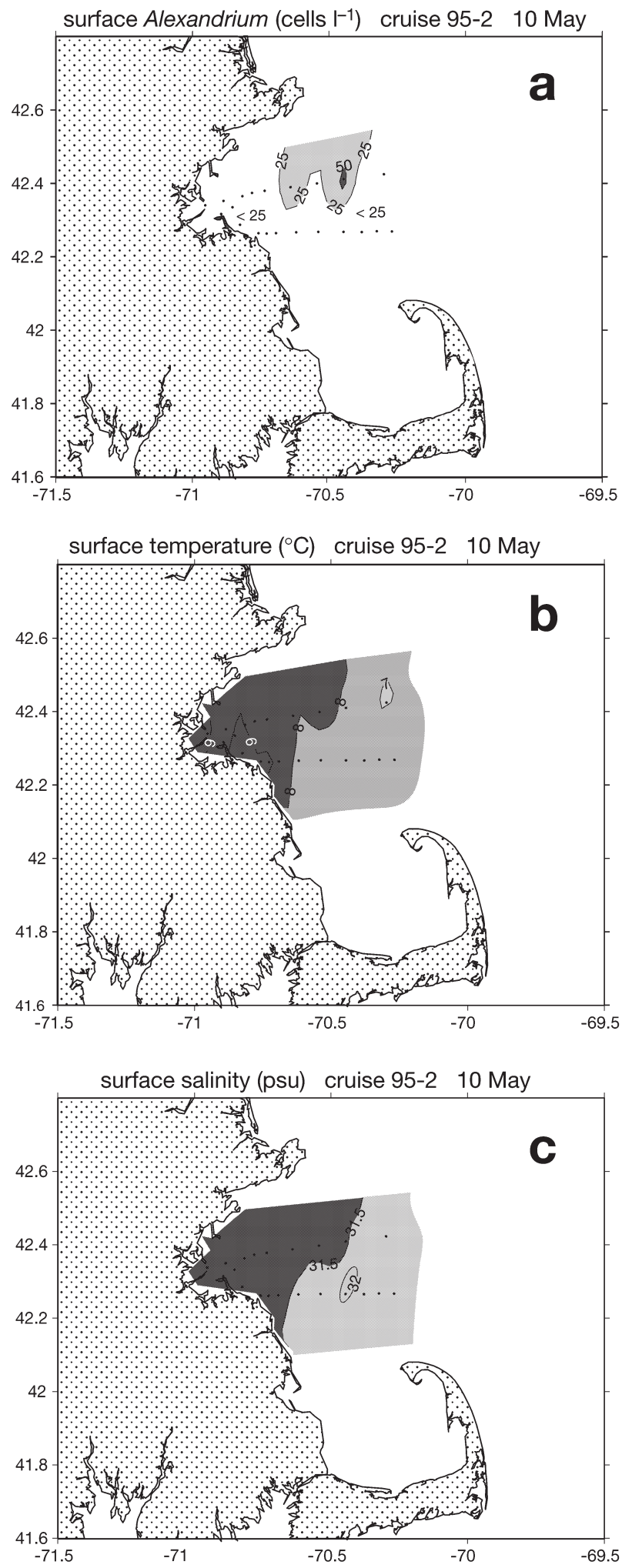

Fig. 2. Surface Alexandrium spp. cell concentrations and hydrographic conditions during Cruise 95MB-2. (a) Maximum abundance of toxic cells during bloom season was ca 50 cells $1^{-1}$ near northwest corner of Stellwagen Bank. (b) Surface temperature was ca $8^{\circ} \mathrm{C}$, and (c) salinity ca $31.25 \mathrm{psu}$

\section{Zooplankton and toxins}

Size-fractionated material from 10 stations (5 fractions per station for a total of 50 samples) was assessed for PSP toxin levels by both the receptor-binding assay (Fig. 4a) and HPLC (Fig. 4b). A toxin signal was detected by at least 1 of the 2 methods in 23 of the 50 sizefractionated samples examined, with HPLC and the receptor-binding assay both reporting toxin on approx. $85 \%$ of the 23 positive samples.

Analyses of size fractions by the receptor-binding assay (Fig. 4a) and HPLC (Fig. 4b) revealed PSP toxin signals primarily in the smallest (20 to $64 \mu \mathrm{m}$ ) and the 2 largest (200 to 500 and $>500 \mu \mathrm{m}$ ) fractions. These represented Alexandrium cells and larger metazoan grazers, respectively. Toxin was in most cases absent from the 2 intermediate fractions (64 to 100 and 100 to $200 \mu \mathrm{m})$. Also, since the Fig. 4 ordinates are on a logarithmic scale, it should be pointed out that toxin levels measured by HPLC were considerably higher in the $>500 \mu \mathrm{m}$ size fraction (82 to 289 pmol STX equiv $\mathrm{g}^{-1}$ wet wt, mean $=202$, for the 8 stations where toxins were detected) than in the 200 to $500 \mu \mathrm{m}$ size fraction (23 to 122 pmol STX equiv $\mathrm{g}^{-1}$ wet $\mathrm{wt}$, mean $=71$, for the 6 stations where toxins were detected). Receptorbinding assay toxin data were 8 to 210 pmol STX equiv $\mathrm{g}^{-1}$ wet $\mathrm{wt}$, mean $=122$, for the 9 stations where toxins were detected in the $>500 \mu \mathrm{m}$ size fraction, and 42 to 241 pmol STX equiv $\mathrm{g}^{-1}$ wet $\mathrm{wt}$, mean $=142$, for the 7 stations where toxins were detected in the 200 to $500 \mu \mathrm{m}$ size fraction. In terms of overall toxicity, Stns 9, 11 and 15 on Cruise 95MB2 and Stns 10, 11 and 15 on Cruise 95MB5 exhibited the highest levels measured. Cruise 95MB2 was notable in that Alexandrium cell concentrations were the highest of any determined during the 1995 sampling (approx. 50 cells $\mathrm{l}^{-1}$ ) and, likewise, PSP toxin levels in the 20 to $64 \mu \mathrm{m}$ size fraction containing these dinoflagellates were 1 to 2 orders of magnitude above any others measured in this study ( 4 to $40 \times 10^{3}$ pmol STX equiv $\mathrm{g}^{-1}$ wet wt). Toxin levels in the 20 to $64 \mu \mathrm{m}$ size fraction obtained during Cruise 95MB5 were considerably lower, consistent with the undetectable levels of Alexandrium cells at that time. However, on Cruise 95MB5, detectable toxin signals were present in the 200 to 500 and $>500 \mu \mathrm{m}$ size fractions.

\section{Zooplankton abundance and size-fraction community composition}

Total zooplankton abundance from quantitative tows is presented in Table 2. Included are the 10 stations for which toxin levels were obtained with both HPLC and the receptor-binding assay (see Figs. 5 to 14). 

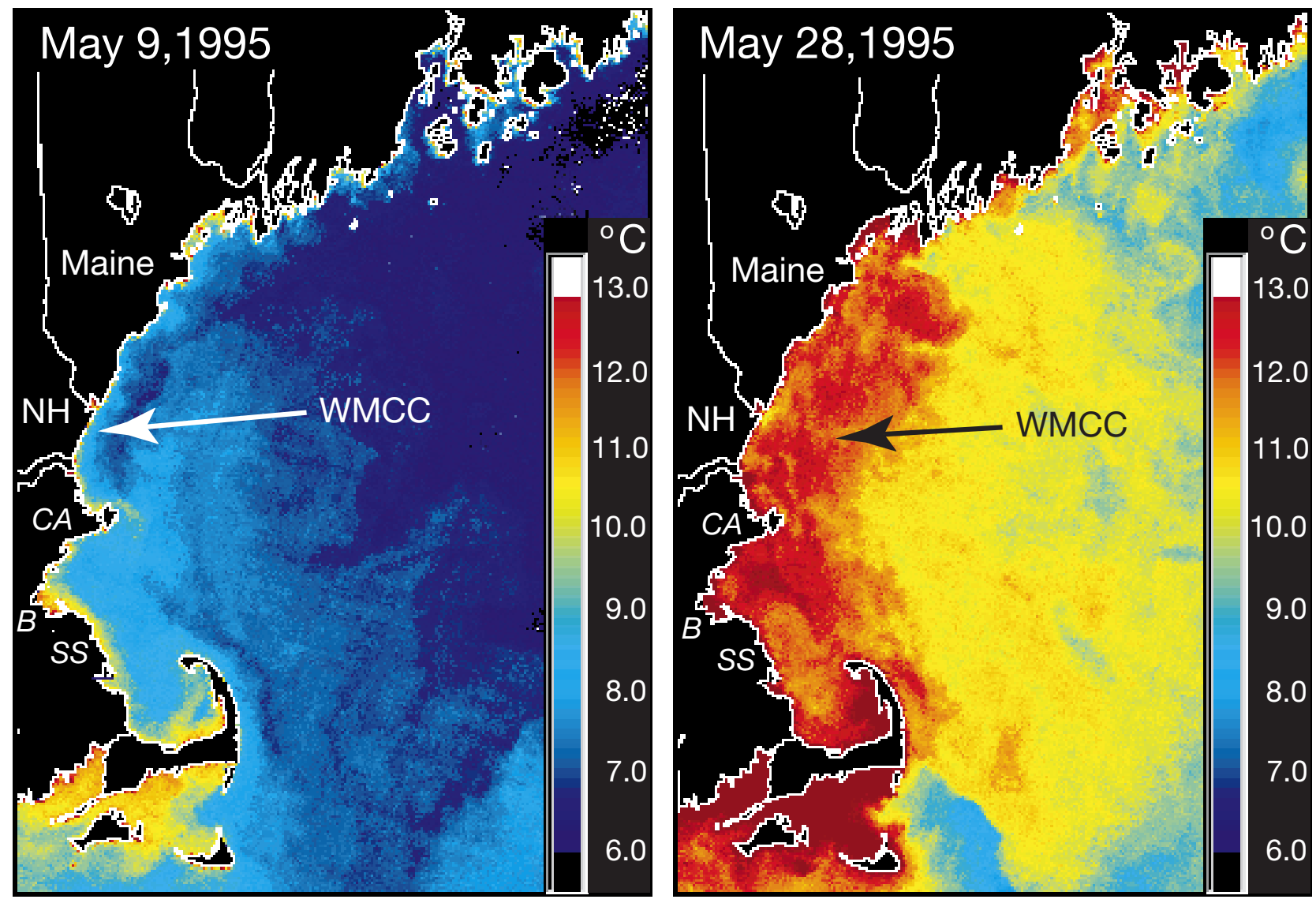

Fig. 3. NOAA Coastwatch sea-surface temperature (SST) imagery of western Gulf of Maine from May 1995. Image on 9 May 1995 (left panel) depicts general downwelling conditions where warmer waters of Western Maine Coastal Current (WMCC; 8.5 to $10.5^{\circ} \mathrm{C}_{i}$ light blue and yellow) entered Massachusetts Bay near Cape Ann (CA) and were compressed against coast along South Shore (SS) near Boston (B). Image was recorded $1 \mathrm{~d}$ before maximum abundance of Alexandrium spp. cells was detected in Massachusetts Bay (see Fig. 2). As vernal warming continued and upwelling-favorable conditions prevailed, imagery on 28 May 1995

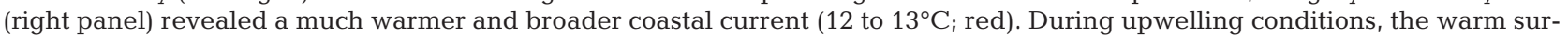
face waters were spread to the east and transport of water into Massachusetts Bay was slowed, preventing further development of the Alexandrium spp. bloom within Massachusetts Bay

Table 2. Raw count of animals per aliquot, aliquot of sample counted, sample vol $\left(\mathrm{m}^{3}\right)$, and total abundances of zooplankton (animals $\mathrm{m}^{-3}$ ) in quantitative samples from stations for which toxins were measured in zooplankton size fractions

\begin{tabular}{|ccccrr|}
\hline Cruise & Station & $\begin{array}{c}\text { Raw } \\
\text { count }\end{array}$ & Aliquot & $\begin{array}{r}\text { Vol } \\
\left(\mathrm{m}^{3}\right)\end{array}$ & $\begin{array}{r}\text { Animals } \\
\mathrm{m}^{-3}\end{array}$ \\
\hline 95MB1 & 31 & 761 & $1 / 512$ & 11.47 & 33970 \\
95MB2 & 01 & 779 & $1 / 256$ & 7.00 & 28489 \\
95MB2 & 09 & 232 & $1 / 1024$ & 5.71 & 41606 \\
95MB2 & 11 & 642 & $1 / 256$ & 3.57 & 46037 \\
95MB2 & 15 & 409 & $1 / 512$ & 2.17 & 96501 \\
95MB2 & 19 & 315 & $1 / 512$ & 5.85 & 27569 \\
95MB4 & 02 & 878 & $1 / 256$ & 1.55 & 145012 \\
95MB5 & 10 & 252 & $1 / 512$ & 4.24 & 30430 \\
95MB5 & 11 & 471 & $1 / 256$ & 2.53 & 47658 \\
95MB5 & 15 & 419 & $1 / 512$ & 4.52 & 47462 \\
& & & & & \\
\hline
\end{tabular}

The total zooplankton assemblage from the quantitative tows and the 200 to 500 and 100 to $200 \mu \mathrm{m}$ size fractions from the qualitative tows were generally dominated by small metazoan zooplankton such as copepod nauplii and adults and copepodites of the small copepod species Oithona similis, Paracalanus parvus, and Pseudocalanus spp. (first histogram on left in Figs. 5 to 14). Conversely, adults and copepodites of larger copepods such as Calanus finmarchicus, Centropages typicus, and Temora longicornis comprised only a minor component of abundance in most quantitative tows for total zooplankton assemblages. Nonetheless, these larger copepods were a disproportionately greater proportion of relative abundance in many of the $>500 \mu \mathrm{m}$ size fractions, which contained most of the PSP toxin signals detected in zooplankton. For 

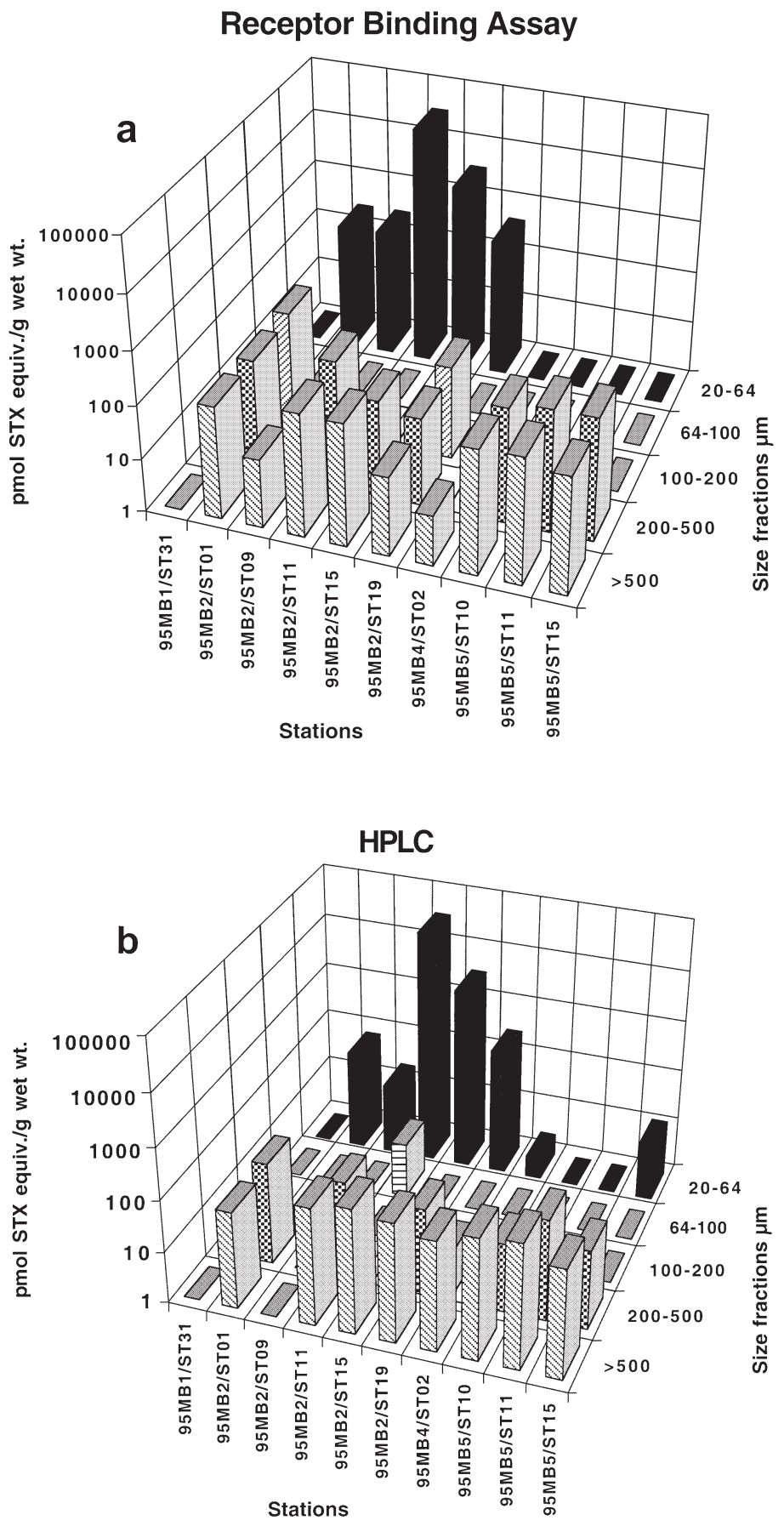

Fig. 4. Results of paralytic shellfish poisoning toxin determinations for size-fractionated zooplankton samples collected during 1995 Massachusetts Bay Cruises 1, 2, 4 and 5. Toxin measurements were performed by (a) receptor-binding assay and (b) HPLC. Toxin contained in sample extracts is expressed as pmol saxitoxin equivalents $\mathrm{g}^{-1}$ wet wt of biomass extracted to permit direct comparison between HPLC and receptor-assay values, as well as within and between cruises. Other than high levels of toxin found in smallest size fraction (20 to $64 \mu \mathrm{m}$ ), which contains the Alexandrium spp. cells, most toxin was contained in larger zooplankton size fractions. ST: station

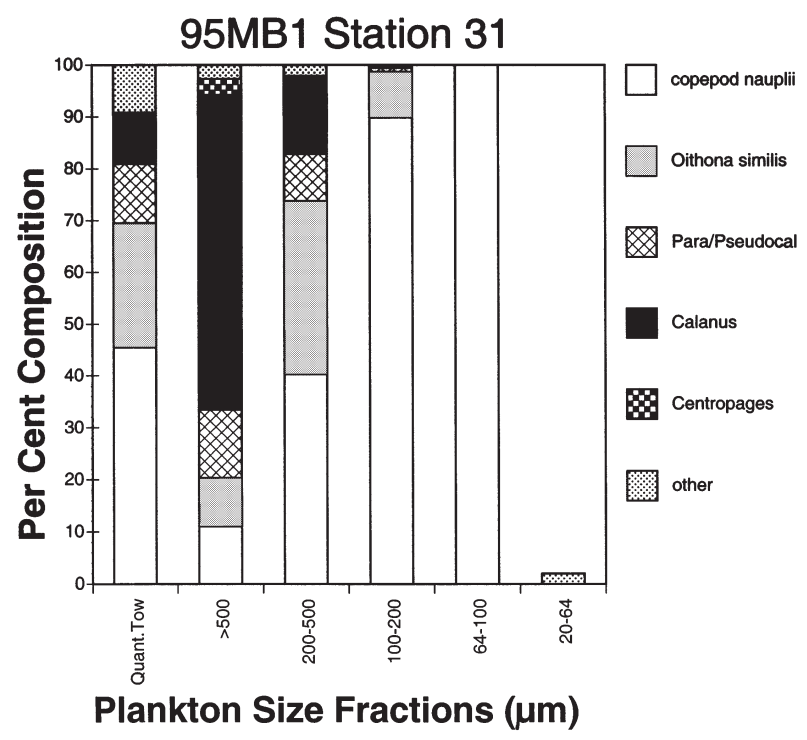

Fig. 5. Percent composition of dominant taxa in quantitative tows and zooplankton size fractions in qualitative tows from Cruise 95MB1, Stn 31. Para/Pseudocal: Paracalanus parvus and Pseudocalanus spp., Calanus: Calanus finmarchicus; Centropages: Centropages typicus

instance, on Cruise 95MB5, the contribution of C. typicus to the $>500 \mu \mathrm{m}$ size fraction comprised $74.63 \%$ at Stn 10 (Fig. 12) and $47.6 \%$ at Stn 15 (Fig. 14), whereas respective contributions of C. typicus to total community abundance were only 5.56 and $4.80 \%$. The combination of C. typicus plus C. finmarchicus at

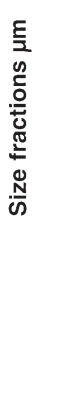

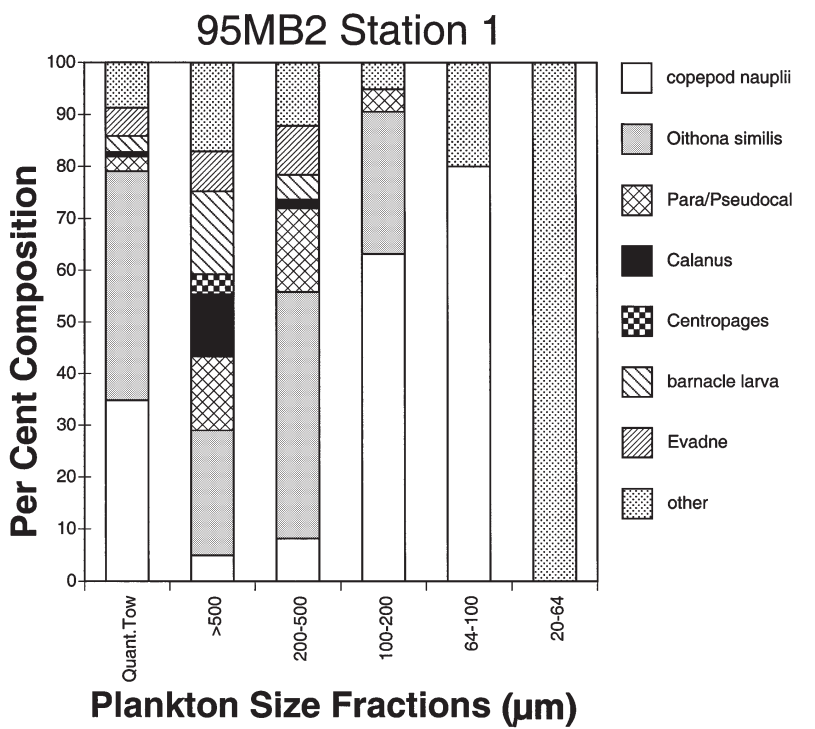

Fig. 6. Percent composition of dominant taxa in quantitative tows and zooplankton size fractions in qualitative tows from Cruise 95MB2, Stn 1. Abbreviations as in Fig. 5 


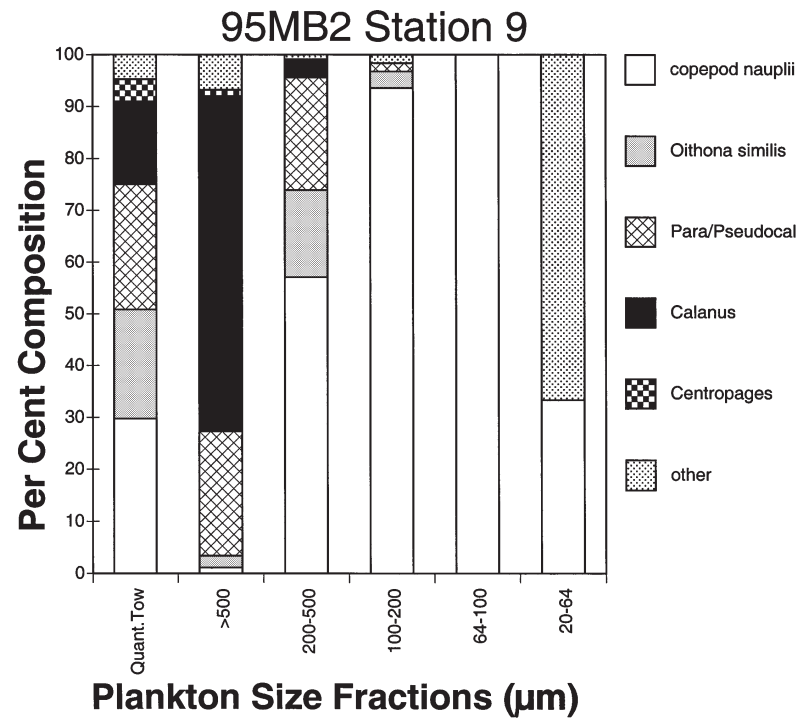

Fig. 7. Percent composition of dominant taxa in quantitative tows and zooplankton size fractions in qualitative tows from Cruise 95MB2, Stn 9. Abbreviations as in Fig. 5

Stn 11 (Fig. 13) comprised $75.7 \%$ of the $>500 \mu \mathrm{m}$ fraction compared to only $20 \%$ of the total zooplankton assemblages represented by the quantitative tows. Toxin levels in the $>500 \mu \mathrm{m}$ fraction were also high relative to the smaller size classes at these stations. Similarly, at other stations with high toxicity, the copepods T. longicornis and C. typicus were more predominant (19.16 and $3.41 \%$, respectively) in $>500 \mu \mathrm{m}$ fractions than in quantitative tow assemblages (3.19 and $0.23 \%$,

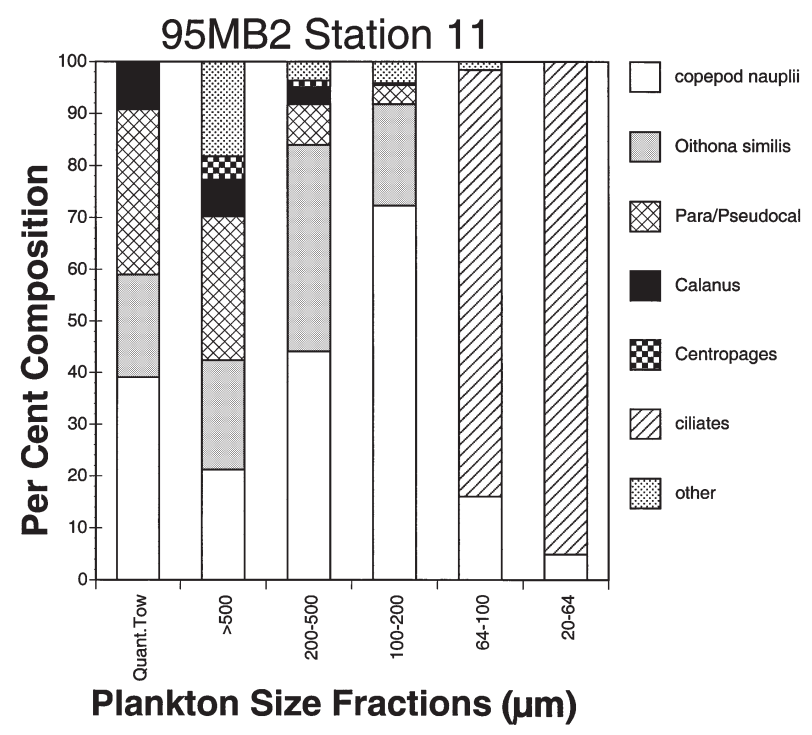

Fig. 8. Percent composition of dominant taxa in quantitative tows and zooplankton size fractions in qualitative tows from Cruise 95MB2, Stn 11. Abbreviations as in Fig. 5

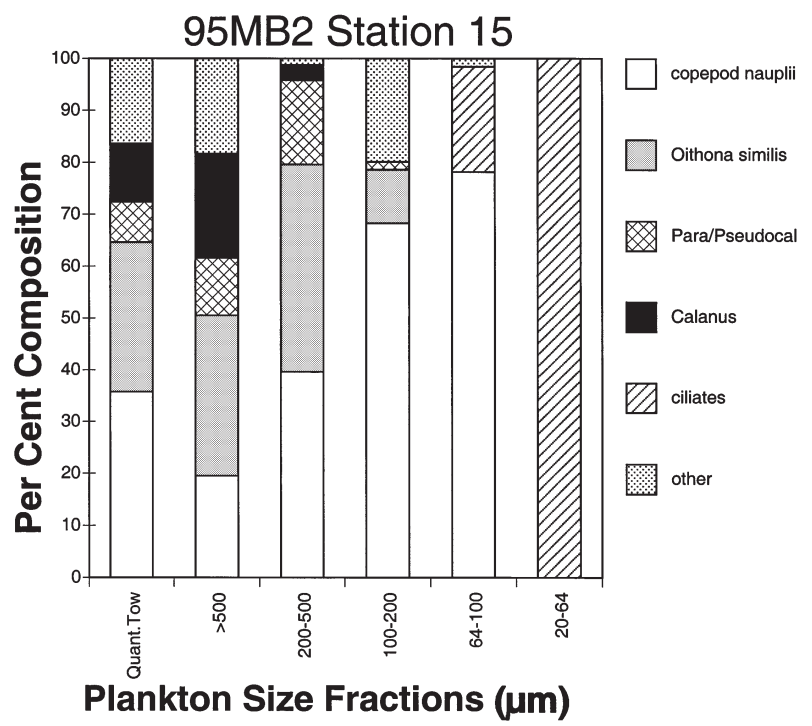

Fig. 9. Percent composition of dominant taxa in quantitative tows and zooplankton size fractions in qualitative tows from Cruise 95MB2, Stn 15. Abbreviations as in Fig. 5

respectively) (Cruise 95MB4, Stn 2, Fig. 11). There were, however, other stations with high toxicity where the relative proportions of large and small copepods in quantitative tows and $>500 \mu \mathrm{m}$ fractions were more similar to each other, such as on Cruise 95MB2 at Stns 1 (Fig. 6), 11 (Fig. 8), 15 (Fig. 9), and 19 (Fig. 10). Also, C. finmarchicus disproportionately dominated relative abundance in the $>500 \mu \mathrm{m}$ fraction at some stations such as Cruise 95MB1, Stn 31 (Fig. 5) and

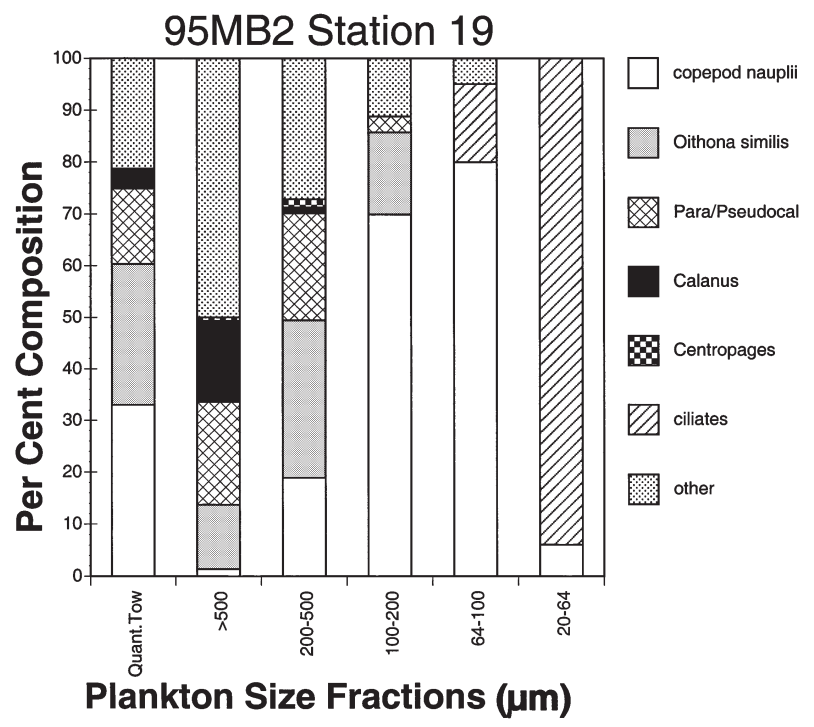

Fig. 10. Percent composition of dominant taxa in quantitative tows and zooplankton size fractions in qualitative tows from Cruise 95MB2, Stn 19. Abbreviations as in Fig. 5 


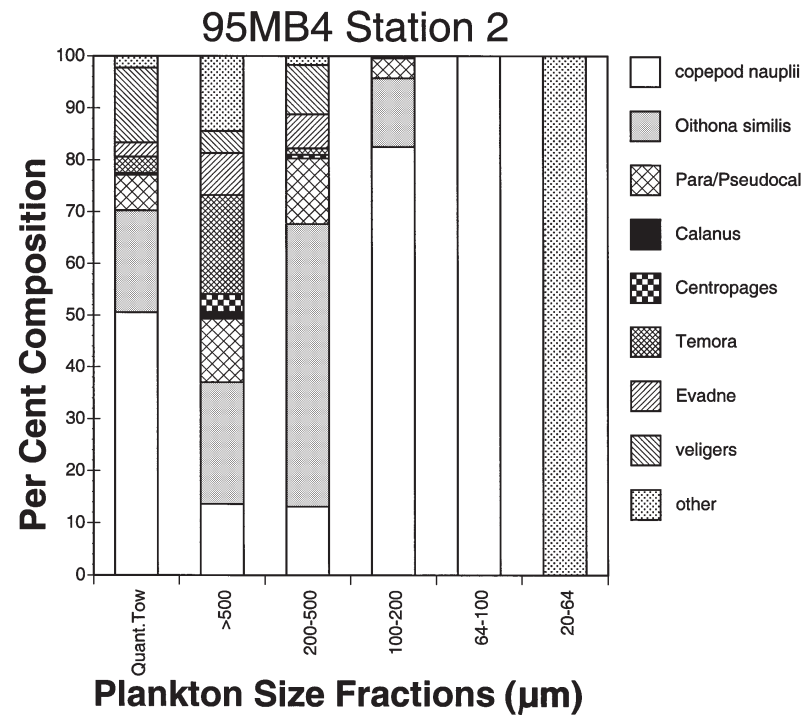

Fig. 11. Percent composition of dominant taxa in quantitative tows and zooplankton size fractions in qualitative tows from Cruise 95MB4, Stn 2. Temora: Temora longicornis; other abbreviations as in Fig. 5

Cruise 95MB2, Stn 9 (Fig. 7) (60.69 and 64.77\%, respectively in the $>500 \mu \mathrm{m}$ fraction, compared to 9.59 and $15.95 \%$, respectively in quantitative tows), even when toxicity in this fraction was low.

\section{DISCUSSION}

The discovery that the highest 'non-algal' PSP toxin levels occurred primarily in the larger, less-abundant

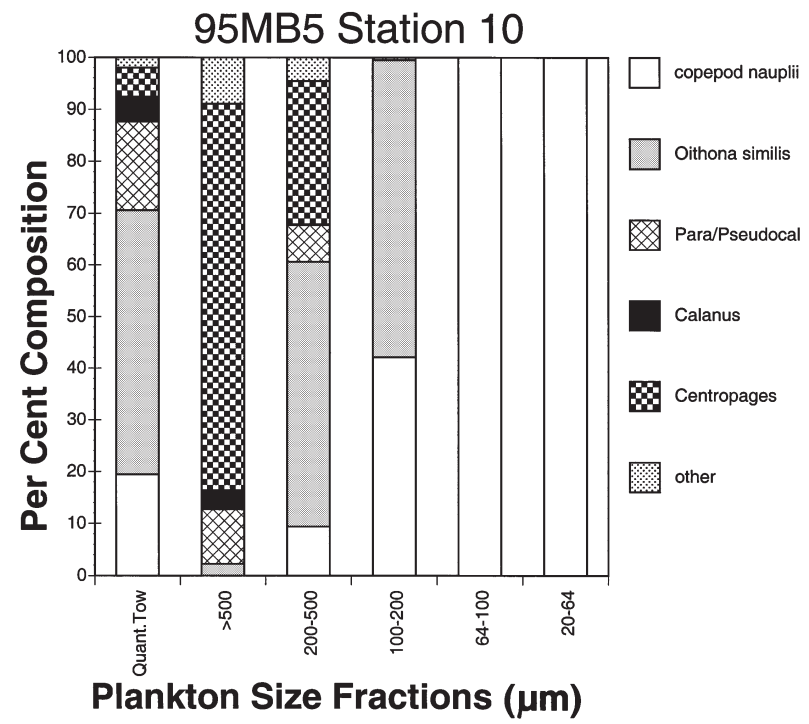

Fig. 12. Percent composition of dominant taxa in quantitative tows and zooplankton size fractions in qualitative tows from Cruise 95MB5, Stn 10. Abbreviations as in Fig. 5

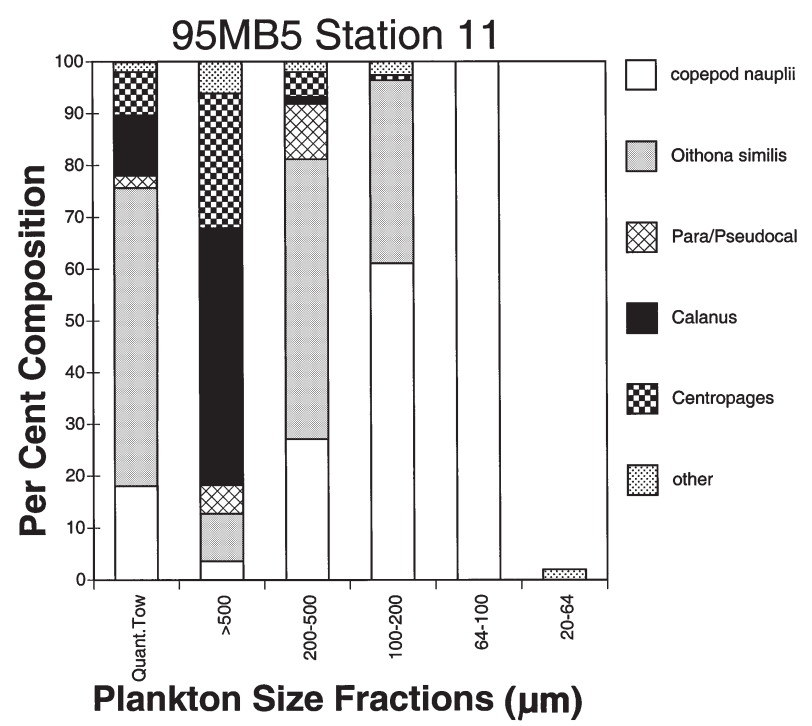

Fig. 13. Percent composition of dominant taxa in quantitative tows and zooplankton size fractions in qualitative tows from Cruise 95MB5, Stn 11. Abbreviations as in Fig. 5

copepods of the $>500 \mu \mathrm{m}$ size fraction is an important finding. Our HPLC and receptor-assay data provide compelling evidence for the transfer of phytoplankton toxins to zooplankton size fractions dominated by large grazers, which are both direct consumers of Alexandrium cells, as well as prey of animals at higher trophic levels. Such a trend was unexpected because these larger copepods accounted for only a minor portion of total mesozooplankton abundance. Absolute confirmation of this route for PSP trophic toxin trans-

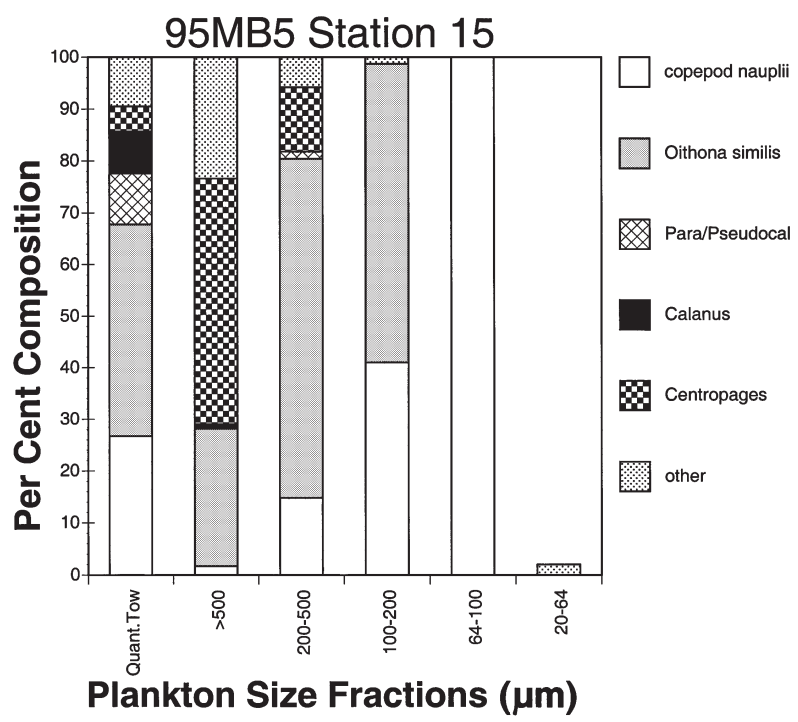

Fig. 14. Percent composition of dominant taxa in quantitative tows and zooplankton size fractions in qualitative tows from Cruise 95MB5, Stn 15. Abbreviations as in Fig. 5 
fer by tandem mass spectrometry is currently being pursued.

The overwhelming numerical dominance of mesozooplankton assemblages in Massachusetts Bay by copepod nauplii and small copepods such as Oithona similis has been noted previously (Turner 1994), but it appeared that these small metazoans did not play a direct role in the trophic transfer of PSP toxins to upper levels of the food web during our study. Although the nauplii- and Oithona-dominated 200 to $500 \mu \mathrm{m}$ size fraction exhibited measurable toxin levels in 6 of 10 samples, these values were generally far lower than for the $>500 \mu \mathrm{m}$ fraction. Similarly, the abundant protistan microzooplankton in most of the 64 to $100 \mu \mathrm{m}$ size fractions appear to be comparatively unimportant linkages in toxin trophic transfer.

The HPLC is currently the standard method employed for estimating concentrations of individual PSP toxin derivatives. In this comparative examination of field material encompassing both algal and zooplankton size fractions, we observed good agreement between HPLC and saxitoxin receptor-binding assay values. Our findings demonstrate that the PSP toxin activity detected by the receptor assay corresponds closely to HPLC-based estimates of these toxins. Moreover, the receptor assay's rapid, high-throughput format makes it especially useful for screening large numbers of samples and identifying those for which a more detailed, yet time consuming, HPLC analysis might be appropriate.

The receptor-binding assay shows great potential for monitoring toxicity in the water column. Receptor assay measurements of toxins extracted from the plankton were sensitive enough to detect toxic activity in the particulate fractions that were retained on sieves, even when no shellfish toxicity was recorded in shellfish at nearshore PSP monitoring stations in Massachusetts Bay. Reasons for this might include: (1) Alexandrium populations were generally offshore and not available to inshore shellfish, even during the downwelling period, and (2) based upon our experience in this region, Alexandrium abundances of 50 cells $\mathrm{l}^{-1}$ are not sufficient to cause shellfish toxicity measurable by mouse bioassay, the method used in shellfish-toxicity monitoring programs. Thus, for offshore waters where benthic shellfish may not be readily harvestable, or even in contact with near-surface blooms, receptor-assay measurements on plankton samples from net tows could serve to monitor for toxicity, even when Alexandrium cells are present at low abundance.

Although uptake and depuration rates of saxitoxins from zooplankters such as copepods are not well understood, it is likely that the toxins were transferred from Alexandrium cells to the larger-sized copepods during the southerly transport of water within the Western Maine Coastal Current. Shellfish toxicity was much higher along the southern Maine coast during this time, suggesting that the possibility that Alexandrium populations might have been extensively grazed down by the time the water mass reached Massachusetts Bay (approx. 1 to 2 wk transit time depending on wind conditions). Evidence consistent with this scenario was particularly apparent during Cruise 95MB-2 (10 May), when maximum Alexandrium cell abundances in Massachusetts Bay $\left(50\right.$ cells $\left.\mathrm{l}^{-1}\right)$ were still so low as to be near detection limits, but toxin levels at Stns 11, 15 and 19 were the highest recorded (Fig. 4)

Once toxins are sequestered in larger zooplankton, they may become less available to shellfish, since these zooplankton generally occur more offshore, away from nearshore shellfish beds. Even if these larger zooplankters are transported inshore during downwelling conditions, suspension-feeding bivalves generally do not eat them.

Since molecular evidence indicates that populations of the copepod Calanus finmarchicus are genetically homogeneous throughout the Gulf of St. Lawrence, Gulf of Maine, and Georges Bank regions (Bucklin et al. 1996), many of the copepods in Massachusetts Bay are also likely to be advected from the north by the Western Maine Coastal Current. If larger copepods substantially graze upon Alexandrium during this journey, this may prevent shellfish toxicity in the southern domain of the Western Maine Coastal Current in some years. Furthermore, since C. finmarchicus (Turriff et al. 1995) and Centropages hamatus (Turner et al. 1998a) have been shown to accumulate Alexandrium toxins through feeding, uptake of such toxins by large copepods may make those toxins more available to pelagic zooplanktivorous consumers such as baleen whales. More data on PSP toxin-depuration rates for zooplankton are needed to more critically evaluate this possibility.

Our finding of disproportionate levels of PSP toxins in larger zooplankton size fractions is of particular interest, since right whales Eubalaena glacialis observed in these waters in early spring are known to feed primarily on large copepods such as species of Calanus and Centropages (Mayo \& Marx 1990). Also, humpback whales Megaptera novaeangliae occur in these waters in late spring and summer, and mortalities of humpback whales in the Cape Cod region (Geraci et al. 1989) were attributed to vectorial intoxication with Alexandrium toxins from ingested mackerel Scomber scombrus, which are known to feed primarily upon Calanus finmarchicus and other large copepods (Bigelow \& Schroeder 1953, p. 320). Further, Nisbet (1983) recorded a kill of $>70$ common terns 
Sterna hirundo in the Cape Cod region following ingestion of zooplanktivorous sand lance Ammodytes americanus that were shown to contain PSP toxins from Alexandrium spp. Vectorial intoxication of other upper-trophic-level marine vertebrates with several other types of phycotoxins have been reviewed by Turner \& Tester (1997) and Turner et al. (1998b).

The low toxin levels in microzooplankton size fractions are the inverse of the pattern reported by White (1979) during an Alexandrium bloom in the Bay of Fundy. There, toxin content progressively declined from smaller to larger zooplankton size fractions. These inconsistancies are likely to reflect real variability in patterns of toxin movement through zooplankton communities during different blooms. However, part of the explanation may also lie in the greater sensitivity for measurement of PSP toxins by HPLC and receptor-binding assay methods ( 2 to 3 orders of magnitude), compared to the mouse bioassay methods that were used by White. White (1981) noted, for example, that in order to obtain reliable PSP measurements in zooplankton with the mouse bioassay, each sample required approx. $10^{5}$ copepods. Our methods would have permitted detection of far lower PSP toxin levels contained in larger zooplankton size fractions comprising a small percentage of the total zooplankton numerical abundance.

In summary, we have presented compelling evidence that PSP toxins from Alexandrium can accumulate in larger-sized copepods in Massachusetts Bay. This occurred at a time when Alexandrium cell abundance was minimal, and there was no recorded shellfish toxicity in the sampling area. Our findings suggest that toxin accumulation in copepods may have occurred through grazing during southward transport of Alexandrium cells in the Western Maine Coastal Current. The ability to detect low levels of PSP toxins in zooplankton was facilitated by sensitive HPLC analyses and receptor-binding assays. Disproportionate accumulation of toxins in larger, less-abundant copepods may pose a threat of vectorial intoxication to endangered whales that inhabit these waters, and feed upon such copepods, during the spring-summer red tide season.

Acknowledgements. We appreciate the shipboard and technical assistance of Jean A. Lincoln, David A. Gauthier, and Shannon Wagner, and the able seamanship of the crew of the University of Massachusetts Dartmouth research vessel, RV 'Lucky Lady', particularly Captains John Gage and Ron Rock. This research was supported by grants from the National Sea Grant College Program Office, US Department of Commerce, Grant NA46RG0470, WHOI Sea Grant Project R/B-140, the Massachusetts Water Resources Authority, the ECOHABGOM (Ecology and Oceanography of Harmful Algal Blooms Gulf of Maine) Program, NOAA/NOS/CCEHBR operational funds, and the University of Massachusetts Dartmouth. Contribution 10021 from the Woods Hole Oceanographic Institution, Contribution 00-03-01 from CMAST (Center for Marine Science and Technology) of the University of Massachusetts Dartmouth, and Contribution 10 of the US ECOHAB Program, sponsored by NOAA Grant 96OP0099 and NSF Grant OCE 9808173.

\section{LITERATURE CITED}

Adachi M, Sako Y, Ishida Y (1993) The identification of conspecific dinoflagellates Alexandrium tamarense from Japan and Thailand by monoclonal antibodies. Nippon Suisan Gakk 59:327-332

Anderson DM (1997) Bloom dynamics of toxic Alexandrium species in the northeastern U.S. Limnol Oceanogr 42: 1009-1022

Anderson DM, White AW (1992) Marine biotoxins at the top of the food chain. Oceanus 35(3):55-61

Anderson DM, Kulis DM, Doucette GJ, Gallagher JC, Balech E (1994) Biogeography of toxic dinoflagellates in the genus Alexandrium from the northeastern United States and Canada. Mar Biol 120:467-478

Baden DG, Trainer VL (1993) Mode of action of toxins of seafood poisoning. In: Falconer IR (ed) Algal toxins in seafood and drinking water. Academic Press, London, p 49-74

Bigelow HB, Schroeder WC (1953) Fishes of the Gulf of Maine. US Fish Wildl Serv Fish Bull 74, 53:1-577

Bucklin A, Sundt RC, Dahle G (1996) The population genetics of Calanus finmarchicus in the North Atlantic. Ophelia 44:29-45

Cembella AD, Milenkovic L, Doucette GJ, Fernandez M (1995) In vitro biochemical methods and mammalian bioassays for phycotoxins. In: Hallegraeff GM, Anderson DM, Cembella AD (eds) Manual on harmful marine microalgae. UNESCO, Paris, p 177-228

Doucette GJ, Logan MM, Ramsdell JS, Van Dolah FM (1997) Development and preliminary validation of a microtiter plate-based receptor binding assay for paralytic shellfish poison toxins. Toxicon 35:625-636

Franks PJS, Anderson DM (1992) Alongshore transport of a toxic phytoplankton bloom in a buoyancy current: Alexandrium tamarense in the Gulf of Maine. Mar Biol 112: 153-164

Geraci JR, Anderson DM, Timperi RJ, St. Aubin DJ, Early GA, Prescott JH, Mayo CA (1989) Humpback whales (Megaptera novaeangliae) fatally poisoned by dinoflagellate toxin. Can J Fish Aquat Sci 46:1895-1898

Guillard RRL (1973) Division rates. In: Stein JR (ed) Handbook of phycological methods. Cambridge University Press, Cambridge, p 289-311

Keafer BA, Anderson DM (1993) Use of remotely-sensed sea surface temperatures in studies of Alexandrium tamarense bloom dynamics. In: Smayda TJ, Shimizu Y (eds) Toxic phytoplankton blooms in the sea. Elsevier Science BV, Amsterdam, p 763-768

Lefebvre CA, Powell CL, Busman M, Doucette GJ, Moeller PDR, Silver JB, Miller PE, Hughes MP, Singaram S, Silver MW, Tjeerdema RS (1999) Detection of domoic acid in northern anchovies and California sea lions associated with an unusual mortality event. Nat Toxins 7:85-92

Mayo CA, Marx MK (1990) Surface foraging behaviour of the North Atlantic right whale, Eubalaena glacialis, and associated plankton characteristics. Can J Zool 68: 2214-2220 
Moestrup Ø, Larsen J (1990) Some comments on the use of the generic names Ptychodiscus and Alexandrium. In: Granéli E, Sundström B, Edler L, Anderson DM (eds) Toxic marine phytoplankton. Elsevier Science BV, Amsterdam, p 78-81

Nisbet ICT (1983) Paralytic shellfish poisoning: effects on breeding terns. Condor 85:338-345

Oshima Y (1995) Post-column derivatization HPLC methods for paralytic shellfish poisons. In: Hallegraeff GM, Anderson DM, Cembella AD (eds) Manual on harmful marine microalgae. UNESCO, Paris, p 81-94

Oshima Y, Bolch CJ, Hallegraeff GM (1992) Toxin composition of resting cysts of Alexandrium tamarense (Dinophyceae). Toxicon 30:1539-1544

Sako Y, Adachi M, Ishida Y (1993) Preparation and characterization of monoclonal antibodies to Alexandrium species. In: Smayda TJ, Shimizu Y (eds) Toxic phytoplankton blooms in the sea. Elsevier Science BV, Amsterdam, p 87-93

Shea D (1997) Analysis of brevetoxins by micellar electrokinetic capillary chromatography and laser-induced fluorescence detection. Electrophoresis 18:277-283

Tester PA, Turner JT, Shea D (2000) Vectorial transport of toxins from the dinoflagellate Gymnodinium breve through copepods to fish. J Plankton Res 22:47-61

Turner JT (1994) Planktonic copepods of Boston Harbor, Massachusetts Bay and Cape Cod Bay, 1992. Hydrobiologia 292/293:405-413

Turner JT, Tester PA (1997) Toxic marine phytoplankton, zooplankton grazers, and pelagic food webs. Limnol Oceanogr 42:1203-1214

Turner JT, Lincoln JA, Cembella AD (1998a) Effects of toxic

Editorial responsibility: Otto Kinne (Editor),

Oldendorf/Luhe, Germany and non-toxic dinoflagellates on copepod grazing, egg production and egg hatching success. In: Reguera B, Blanco J, Fernandez M, Wyatt T (eds) Harmful microalgae. Xunta de Galicia and Intergovernmental Oceanographic Commission of UNESCO Paris, p 379-381

Turner JT, Tester PA, Hansen PJ (1998b) Interactions between toxic marine phytoplankton and metazoan and protistan grazers. NATO ASI Ser, G41:53-474

Turriff N, Runge JA, Cembella AD (1995) Toxin accumulation and feeding behaviour of the planktonic copepod Calanus finmarchicus exposed to the red-tide dinoflagellate Alexandrium excavatum. Mar Biol 123:55-64

Van Dolah FM, Finley EL, Haynes BL, Doucette GJ, Moeller PD, Ramsdell JS (1994) Development of rapid and sensitive high throughput pharmacologic assays for marine phycotoxins. Nat Toxins 2:189-196

White AW (1977) Dinoflagellate toxins as probable cause of an Atlantic herring (Clupea harengus harengus) kill, and pteropods as apparent vector. J Fish Res Board Can 34: $2421-2424$

White AW (1979) Dinoflagellate toxins in phytoplankton and zooplankton fractions during a bloom of Gonyaulax excavata. In: Taylor DL, Seliger HH (eds) Toxic dinoflagellate blooms. Elsevier Science BV, Amsterdam, p 381-384

White AW (1980) Recurrence of kills of Atlantic herring (Clupea harengus harengus) caused by dinoflagellate toxins transferred through herbivorous zooplankton. Can J Fish Aquat Sci 37:2262-2265

White AW (1981) Marine zooplankton can accumulate and retain dinoflagellate toxins and cause fish kills. Limnol Oceanogr 26:103-109

Submitted: August 31, 1999; Accepted: April 6, 2000 Proofs received from author(s): August 21, 2000 